\title{
Optimation 1,2 formulation of meat analog from cowpea (Vigna unguiculata L Walp) protein curds and cocoyams (Xanthosoma sagittifolium) modification starch as filler
}

\author{
Dedin Finatsiyatull ROSIDA ${ }^{1 *}$ (D), Dahlia ELIANARNI ${ }^{1}$, Ulya SAROFA ${ }^{1}$
}

\begin{abstract}
Meat analog is a plant protein product that comes from non-meat materials. The materials were used in this research were cowpea curd protein $(20-30 \%)$ and cocoyam modification starch $(20-30 \%)$ by autoclaving-cooling. This research aimed to ascertain the optimum formulation of cowpea curd protein as a raw material and cocoyam modification starch as a filler in the meat analog. The data obtained were processed with response surface methodology (RSM) to find the optimum formulation. The optimum results of the central composite design (CCD) showed that the moisture response had a 2FI (2-factor interaction) model with a final equation of $\mathrm{Y}=52.05-1.73 \mathrm{X}_{1}+1.16 \mathrm{X}_{2}+1.84 \mathrm{X}_{1} \mathrm{X}_{2}$, where $\mathrm{X} 1 \mathrm{X} 2$ Curd protein ${ }^{\star}$ modified starch. The ash content had a $2 \mathrm{FI}$ model with a final equation of $\mathrm{Y}=2.79-0.71 \mathrm{X}_{1}+0.43 \mathrm{X}_{2}-1.02 \mathrm{X}_{1} \mathrm{X}_{2}$, the fat content had a linear model with a final equation of $\mathrm{Y}=2.59+0.11 \mathrm{X}_{1}+1.26 \mathrm{X}_{2}$, the protein content had a linear model with a final equation of $\mathrm{Y}=18.26+0.62 \mathrm{X}_{1}+0.056 \mathrm{X}_{2}$, the carbohydrate content had a linear model with a final equation of $\mathrm{Y}=24.54+1.17 \mathrm{X}_{1}-2.38 \mathrm{X}_{2}$, the texture value had a mean model with a final equation of $Y=0.072$, and the color value had a mean model with a final equation of $Y=30.41$. The optimum condition of cowpea curd protein was added by $30 \%$ and cocoyam modification starch was added by $30 \%$ a with response of water content $50.92 \%$, ash content $2.11 \%$, protein content $18.97 \%$, fat content $4.18 \%$, carbohydrate content $23.82 \%$, texture $0.075(\mathrm{~mm} / \mathrm{gr} / \mathrm{dt})$, and color $22.44(\mathrm{~L})$.
\end{abstract}

Keywords: cocoyams; curd protein; meat analog; modification starch; response surface methodology.

Practical Aplication: Ascertain the optimum formulation of cowpea curd protein as a raw material and cocoyam modification starch as a filler in the meat analog.

\section{Introduction}

Meat is a protein resource is consumed by society generally. With a high protein content, meat also has a high saturated acid content. A large amount of meat consumed causes diseases, so we need to replace this product with alternatives that can supply the protein needed, but that has a good effect. One alternative is the meat analog. Meat analog is a product made from protein and carbohydrate sources. Soy protein and gluten flour are raw materials that have been used for a long time (Li et al., 2007).

In this study, the protein source that is used is cowpeas with a protein content of $22.5 \%$ and low-fat content (Antova et al., 2013). The study minimizes the use of gluten flour, which is replaced with filler consisting of cocoyam with a carbohydrate content of $36 \%$. We took the starch from the cocoyam and modified it with autoclaving-cooling for repairing its physical characteristics (Boakye et al., 2018). Meat analog resembles meat products, so the texture and protein content must be replaced.

The essence of RSM is to use an experimental model to find the optimal response. This statistical tool can be used to standardize and optimize process variables for different products (Jalarama et al., 2013) and food-processing operations (Madamba, 2002). This research aimed to ascertain the optimum formulation of cowpea curd protein as a raw material and cocoyam modification starch as a filler in the meat analog.
Like most meat substitutes, this one uses soybean-based ingredients not following micronutrient formulations in real meat (Ahirwar et al., 2015). So the study uses a combination of raw material formulations and fillers to make a meat analog with a better nutritional profile. In this formulation optimization, the RSM method was used.

\section{Materials and methods}

\subsection{Raw material products}

The cowpeas, cocoyam, gluten flour, mushrooms, salt, spices, water, and margarine were obtained from the Ngaban Sidoarjo East Java Market. The modification of the cocoyam starch was done by an autoclaving-cooling method.

\subsection{Design of experiment}

This research is conducted in two steps. The first stage is preceded by a study using the two-factor Complete Randomized Design (CRD) method. The first factor, Curd-protein for cowpea, is $20 \%, 25 \%, 30 \%$. The second factor, modified tuber starch, is $20 \%, 25 \%, 30 \%$. after getting the best treatment from RAL will be followed by RSM (Response Surface Methodology). 
The second stage of the research was carried out using RSM (Response Surface methodology). Response Surface Methodology (RSM) is a set of mathematical methods from statistical techniques that aim to load models and analyze of responses that are influenced by several variables. Central Composite Design (CCD) in RSM is used to design combinations in experiments in making analog meat. This is based on the proximate content that meets SNI (Indonesian National for Standardization), has a color that is almost the same as other sausages, has appropriate texture, and the most preferred sensory results. This best treatment was made at the central level (0) in RSM research. There are 5 codes in this RSM research, code 0 , code -1 , code +1 , code $-1,414$ and code $+1,414$. Code +1 for cowpea protein curd plus $5 \%$ from the central level (25\%) so that it becomes $30 \%$ and for -1 minus $5 \%$ so that it becomes $20 \%$. Code +1 for modified starch tuber plus 5\% from the intermediate level (25\%) so that it becomes $30 \%$ and -1 reduced by $5 \%$ so that it becomes $20 \%$. Codes $+1,414$ and $-1,414$ are obtained automatically from the RSM application (Myers et al, 2004).

A central composite design (CCD) was applied to determine the combination of curd cowpea protein and modified starch in the manufacture of the meat analog using Design Expert Version 10. Curd cowpea protein $(20 \%, 25 \%, 30 \%)$ and modified starch $(20 \%, 25 \%, 30 \%)$ were independent variables, and water content, ash content, protein content, fat content, carbohydrate content, texture, and color were the response variables. The experimental design of making meat analog can be seen in Table 1 . The factorial design with 13 kinds of experiments consisted of factorial points, central points, and axial points (Sin et al., 2006). The number of opportunities to make mistakes when making decisions was significant. In this study, the level of significance (P-value) was determined, showing that permissible error was $5 \%$, so that the chance of making a mistake was a maximum of $5 \%$ (Ratnawati et al., 2018.). All variables in polynomial regression are said to be significant at level $\mathrm{p}<0.05$, including the model, the coefficient of determination $\left(\mathrm{R}^{2}\right)$ in determining the accuracy of the model. The surface response results from calculations on second-order polynomials using values on each independent variable until the quadratic response (Sin et al., 2006).

Table 1. Sensory test results of Meat analog from Cowpea (Vigna unguiculata L Walp) Curds and Cocoyams (Xanthosoma sagittifolium) Modification Starch as Filler.

\begin{tabular}{ccccc}
\hline \multirow{2}{*}{$\begin{array}{c}\text { Curd } \\
\text { Protein (\%) }\end{array}$} & $\begin{array}{c}\text { Modification } \\
\text { Starch }(\%)\end{array}$ & \multicolumn{3}{c}{ Sensory test results } \\
\cline { 3 - 5 } 20 & 20 & $6.2 \mathrm{~d}^{*}$ & $6.06^{\mathrm{e}}$ & $5.7^{\mathrm{e}}$ \\
20 & 25 & $6.2^{\mathrm{d}}$ & $6.06^{\mathrm{e}}$ & $5.8^{\mathrm{d}}$ \\
20 & 30 & $6.4^{\mathrm{c}}$ & $6.6^{\mathrm{b}}$ & $5.8^{\mathrm{d}}$ \\
25 & 20 & $6.7^{\mathrm{b}}$ & $6.09^{\mathrm{e}}$ & $6.1^{\mathrm{c}}$ \\
25 & 25 & $8^{\mathrm{a}}$ & $8.1^{\mathrm{a}}$ & $7.9^{\mathrm{a}}$ \\
25 & 30 & $5.8^{\mathrm{e}}$ & $6.3^{\mathrm{d}}$ & $6.3^{\mathrm{b}}$ \\
30 & 20 & $5.3^{\mathrm{f}}$ & $5.9^{\mathrm{f}}$ & $5.4^{\mathrm{f}}$ \\
30 & 25 & $4.9^{\mathrm{g}}$ & $6.1^{\mathrm{e}}$ & $5.1^{\mathrm{g}}$ \\
30 & 30 & $4.6^{\mathrm{h}}$ & $6.4^{\mathrm{c}}$ & $4.6^{\mathrm{h}}$ \\
\hline
\end{tabular}

${ }^{*}$ The notation ${ }^{\mathrm{a}-\mathrm{h}}$ shows the significance of the formula or treatment. It shows statistically different results.
The first-order model on two variables can be said as Equation 1:

$y=\beta_{0}+\beta_{1} x_{1}+\beta_{2} x_{2}+\varepsilon$

The general description of the first-order model with the interaction can be said as Equation 2:

$y=\beta_{0}+\beta_{1} x_{1}+\beta_{2} x_{2}+\beta_{12} x_{1} x_{2}+\varepsilon$

The description of a broader model called a second-order model can be notified as as Equation 3(Montgomery, 2008):

$\mathrm{y}=\beta_{0}+\beta_{1} \mathrm{x}_{1}+\beta_{2} \mathrm{x}_{2}+\beta_{12} \mathrm{x}_{1} \mathrm{x}_{2}+\beta_{11} \mathrm{x}^{2}{ }_{11}+\beta_{22} \mathrm{x}^{2}{ }_{22} \varepsilon$

\subsection{The making of protein curd}

The obtained cowpea is washed and soaked in water for 12 hours, and then the areca shell is peeled clean. Washed beans are milled with the addition of water (1:8) and then filtered only from the juice. The obtained cowpea filtrate is deposited and then boiled until $95^{\circ} \mathrm{C}$ for five minutes. The boiled filtrate is cooled until $75^{\circ} \mathrm{C}$, and acetic acid is added to $\mathrm{pH}$ 4.5-4.6. Curdprotein is formed, and whey is separated from the cowpea filtrate. The curd is pressed until it becomes solid and then steamed for 30 minutes (Rekha \& Vijayalakshmi, 2010).

\subsection{The making of modification starch}

The cocoyams are peeled and washed thoroughly. The cocoyam is shredded, crushed, and then squeezed until the filtrate is obtained. The filtrate is deposited for eight hours, and the precipitate is taken and then dried in a cabinet dryer. The dried starch is smoothed and sifted using a 100-mesh sieve. The starch is added to $20 \%$ water and packed in HDPE plastic and then autoclaved for 15 minutes at $121{ }^{\circ} \mathrm{C}$. After that, the starch is stored in the refrigerator at a temperature of $4{ }^{\circ} \mathrm{C}$ for 24 hours. The modified starch is dried for four hours at $50{ }^{\circ} \mathrm{C}$ and then sifted with a 100-mesh sieve (Sugiyono et al., 2009).

\subsection{The making of the meat analog}

The curd of cowpea protein and modified starch of cocoyam tuber are weighed according to the formulation determined by the application, and then to this are added $20 \%$ oyster mushroom, $20 \%$ gluten, $10 \%$ seasoning, and $20 \mathrm{~mL}$ water, and then formed into a mixture until homogeneous. The formed dough is packaged in a sausage-like sleeve and then boiled for 30 minutes at $1000^{\circ} \mathrm{C}$ (Ahirwar et al., 2015).

\subsection{Product analysis}

The cowpea curd protein, the modification cocoyam starch, and the meat analog product were analyzed for the yield, protein content (Association of Official Analytical Chemists, 1995), water content (Association of Official Analytical Chemists, 1995), fat content (Association of Official Analytical Chemists, 1995), starch content (Association of Official Analytical Chemists, 1995), swelling power (Schoch, 1964), solubility (Schoch, 1964), amylose content, amylopectin levels (by difference), water holding 
Table 2. Design of experiments on making meat analog.

\begin{tabular}{|c|c|c|c|c|c|c|c|c|c|}
\hline \multirow[b]{2}{*}{ Run } & \multicolumn{2}{|c|}{ Variable } & \multicolumn{7}{|c|}{ Response Product of Meat analog } \\
\hline & $\begin{array}{c}\text { Curd protein } \\
\text { (gr) }\end{array}$ & $\begin{array}{c}\text { Modification } \\
\text { starch (gr) }\end{array}$ & Water $(\%)$ & Ash (\%) & Protein (\%) & Fat $(\%)$ & $\begin{array}{c}\text { Carbohydrate } \\
(\%)\end{array}$ & $\begin{array}{c}\text { Texture } \\
\text { (mm/gr/dtk) }\end{array}$ & Color (L) \\
\hline 1 & 30 & 20 & 48.06 & 2.08 & 18.87 & 1.64 & 29.35 & 0.0760 & 18.46 \\
\hline 2 & 25 & 25 & 52.98 & 2.96 & 18.08 & 2.21 & 23.77 & 0.0656 & 34.02 \\
\hline 3 & 30 & 30 & 50.92 & 2.11 & 18.97 & 4.18 & 23.82 & 0.0750 & 22.44 \\
\hline 4 & 25 & 25 & 50.40 & 3.26 & 18.10 & 3.82 & 24.42 & 0.0646 & 39.68 \\
\hline 5 & 25 & 32.0711 & 54.92 & 2.07 & 18.41 & 4.57 & 20.03 & 0.0683 & 32.49 \\
\hline 6 & 25 & 25 & 52.64 & 2.42 & 18.35 & 2.13 & 24.46 & 0.0903 & 34.93 \\
\hline 7 & 32.0711 & 25 & 50.88 & 1.80 & 19.18 & 2.49 & 25.65 & 0.0656 & 33.21 \\
\hline 8 & 17.9289 & 25 & 51.14 & 2.59 & 17.36 & 2.13 & 26.78 & 0.0500 & 27.67 \\
\hline 9 & 25 & 25 & 52.98 & 3.58 & 18.09 & 2.14 & 23.21 & 0.0763 & 36.43 \\
\hline 10 & 25 & 17.9289 & 47.19 & 2.56 & 18.24 & 1.06 & 30.95 & 0.0806 & 31.81 \\
\hline 11 & 20 & 20 & 58.49 & 2.32 & 17.67 & 1.41 & 20.11 & 0.0816 & 32.85 \\
\hline 12 & 25 & 25 & 51.99 & 2.13 & 18.31 & 1.82 & 25.75 & 0.0666 & 22.02 \\
\hline 13 & 20 & 30 & 54.00 & 6.44 & 17.78 & 4.02 & 17.76 & 0.0786 & 29.35 \\
\hline
\end{tabular}

capacity, oil holding capacity (Larrauri et al., 1996), ash content (Association of Official Analytical Chemists, 1995), carbohydrate (by difference), texture, and color.

\section{Results and discussion}

The main parameters that determine the quality of meat analog are water content, protein content, texture, and color. The range of the experiment and the level of the independent variable are determined based on the actual and coded factors. A list of variables and responses can be seen in Table 2 . The results of the central composite design are used to adjust the second-order polynomial equation. Regression analysis in each response showed different models, including 2FI models (moisture content and ash content), linear models (fat content, protein content, and carbohydrate content), and mean models (texture and color). Anova has been calculated, and the statistical model for all responses can be seen in Table 3.

Variations in the levels of independent variables in response to the moisture content, protein content, texture, and color have been presented in the form of 3D surfaces in Figures 1,2, and 3, respectively. Based on the images that have been obtained, the addition of modified starch tuber influenced the water content, the addition of the curds of the cowpea proteins affected the protein content, and the addition of the two factors did not affect the values of texture and color.

\subsection{Sensory testing}

The Sensory quality is the nature of a commodity or food products measured by the sensing process using eyesight, smell (nose), taste (tongue), touch (fingertips), and / or hearing (ears), several important parameters in sensory quality include form, size, color, texture, aroma, and taste (Rahayu \& Nurosiyah, 2012).

Increasing concerns about wellbeing in ethical, social, health, and ecological aspects have increased the number of vegetarians. The replacement of meat protein with plant protein has, therefore, become an important research topic
Table 3. ANOVA and statistical model for meat analog.

\begin{tabular}{lcccc}
\hline \multicolumn{1}{c}{ Parameter } & Water & Protein & Texture & Color \\
\hline $\mathrm{SD}^{*}$ & 2.43 & 0.11 & 0.010 & 6.20 \\
Mean & 52.05 & 18.26 & 0.072 & 30.41 \\
$\mathrm{CV}^{* *}$ & 4.66 & 0.61 & 14.13 & 20.38 \\
Press & 190.82 & 0.18 & $1.468 \mathrm{E}-003$ & 541.11 \\
R square & 0.4776 & 0.9610 & 0 & 0 \\
$\begin{array}{l}\text { Adjusted R } \\
\text { square }\end{array}$ & 0.3035 & 0.9532 & 0 & 0 \\
$\begin{array}{l}\text { Predicted R } \\
\text { square }\end{array}$ & -0.8832 & 0.9456 & -0.1736 & -0.1736 \\
$\begin{array}{l}\text { Adequate } \\
\text { precision }\end{array}$ & 5.343 & 32.537 & & \\
Model & 2FI & Linear & Mean & Mean \\
\hline *SD: Standard Deviation $* *$ CV: Coefficient of Variation. &
\end{tabular}

${ }^{\star}$ SD: Standard Deviation; ${ }^{* *} \mathrm{CV}$ : Coefficient of Variation.

(Apostolidis \& McLeay, 2016; Dekkers et al., 2018). However, meat analogs are still known to be different from meat in terms of color, texture, and taste.

The sensory evaluation was carried out to analyze the differences in the meat analogs. As shown in Table 1, intensity and preference score of color, taste and texture in using curd protein and modification starch treatment.

The results of our study have thus effectively analyzed and presented the possibility of using specific protein and starch to improve the acceptability of meat analogs. The substitution of animal fat in meat analogs while maintaining its sensory and physicochemical profile to ensure its acceptability by vegetarians is a present-day challenge for the food science industry.

The average ratings, standard deviations, and real different test results were initially calculated for all the panelists for each analyzed feature, including appearance/color, taste, and texture.

These values, along with the mean acceptance and mean parameters, are shown in the following Table 1. Mean acceptance of sensory attributes of the 9 samples varies from 4.60 to 8.1. The best cocoyam ranged or best accepted by consumers was 
A

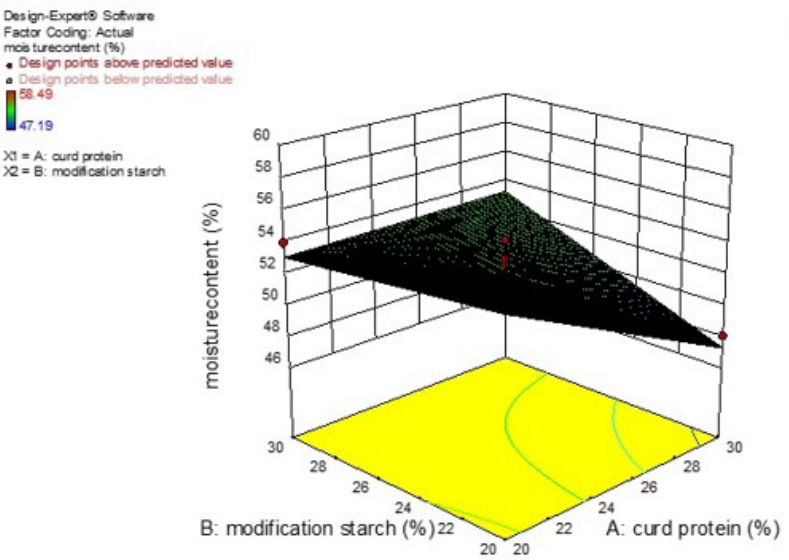

B

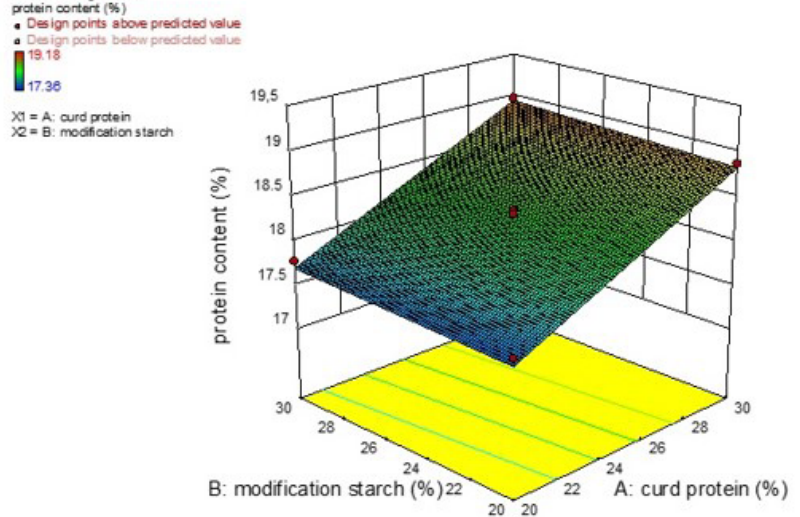

Figure 1. 3D surface of (A) meat analog water content, (B) 3D surface levels of meat analog protein.
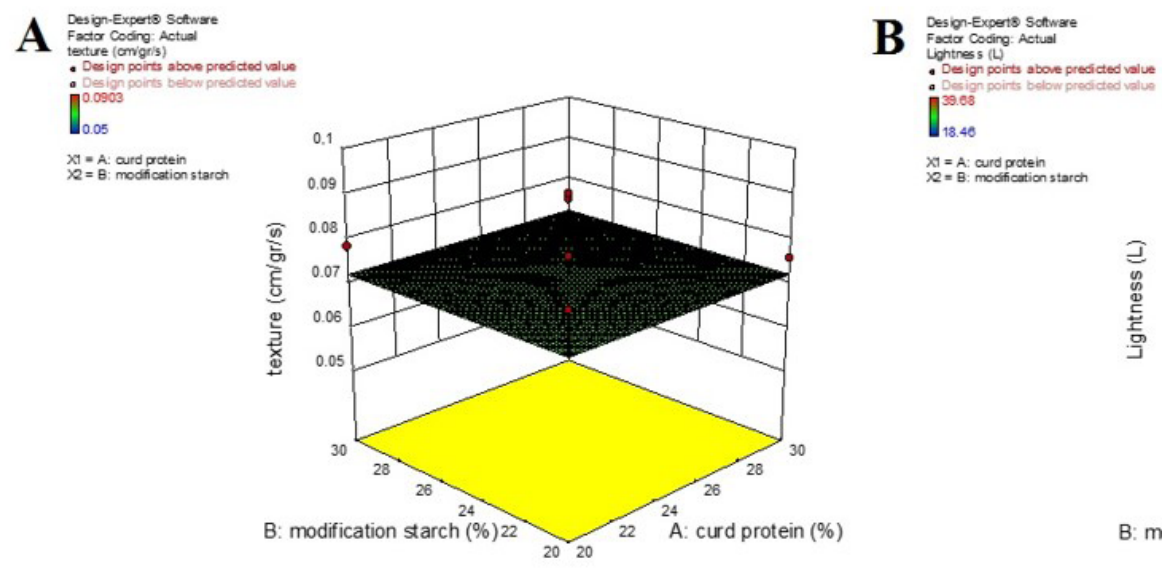

Xi $=$ A: curd protein



Figure 2. 3D surface (A) value of texture meat analog, (B) the color value of meat analog.

sample 5 - meat analog from curd protein $25 \%$ and modification starch $25 \%$ with the mean value of acceptance color 8.0 ; taste 8.1 and texture 7. 9 .

The less accepted or ranged with a mean value of acceptance color 1.6, taste 6.4, and texture 4.6, was sample code 9 - meat analog from curd protein $30 \%$ and modification starch $30 \%$.

\subsection{Water content}

The program's 2FI prediction was chosen to explain the relationship between curd concentration of cowpea protein and modified cocoyam starch to the response of meat analog water content. The surface response to moisture content can be seen in Figure 1A.

$Y=52.05-1.73 X_{1}+1.16 X_{2}+1.84 X_{1} X_{2}$

while $\mathrm{Y}=$ Water content response
$\mathrm{X}_{2}=$ modified starch

$\mathrm{a}=$ constant $(52.05)$

$\mathrm{X}_{1} \mathrm{X}_{2}=$ Curd protein ${ }^{\star}$ modified starch

$\mathrm{X}_{1}=$ Curd protein

Based on the equation 4 , it can be seen that the curd coefficient of the curd protein is -1.73 , showing a decrease in water content, while the modified starch of cocoyam has a coefficient of +1.16 , indicating an increase in moisture content. Similarly, the interaction between curd cowpea protein and modified cocoyam starch has a +1.84 coefficient, which indicates an increase in water content.

The more the curd cowpea protein was added, the lower the water content we measured. This could be due to the considerable amount of water content in the curd of cowpea protein evaporating during the boiling process. Abbasi et al. 
A

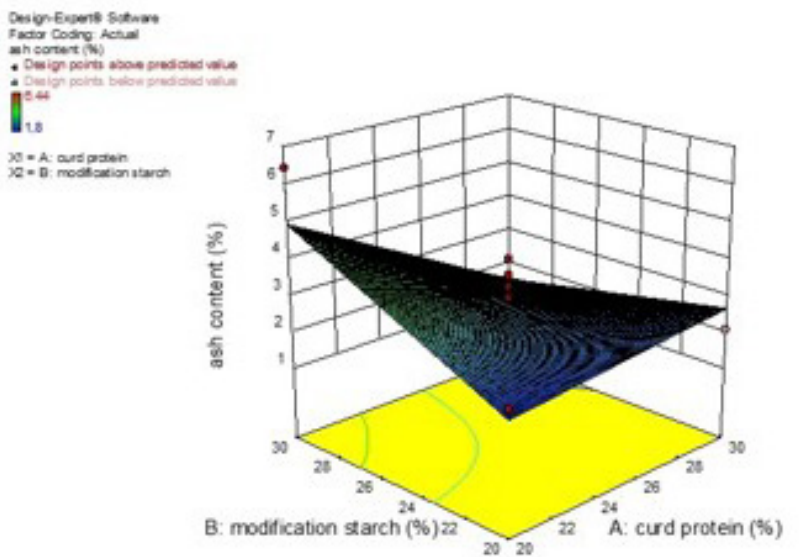

B

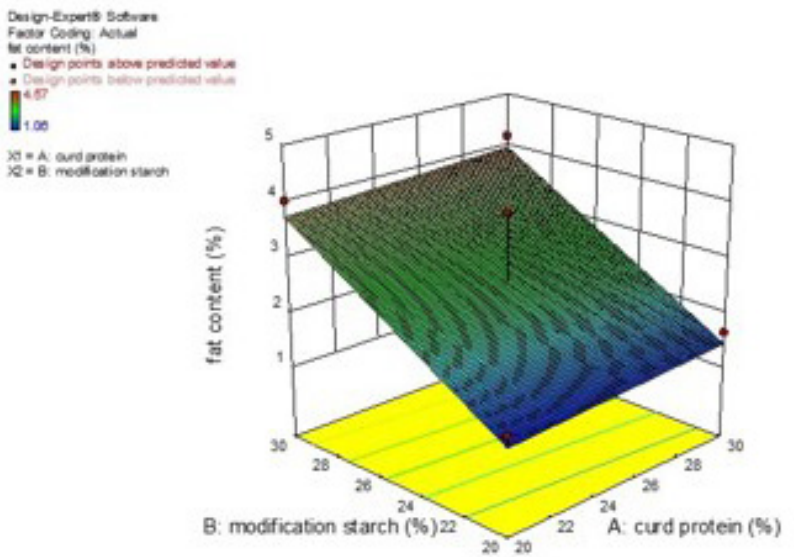

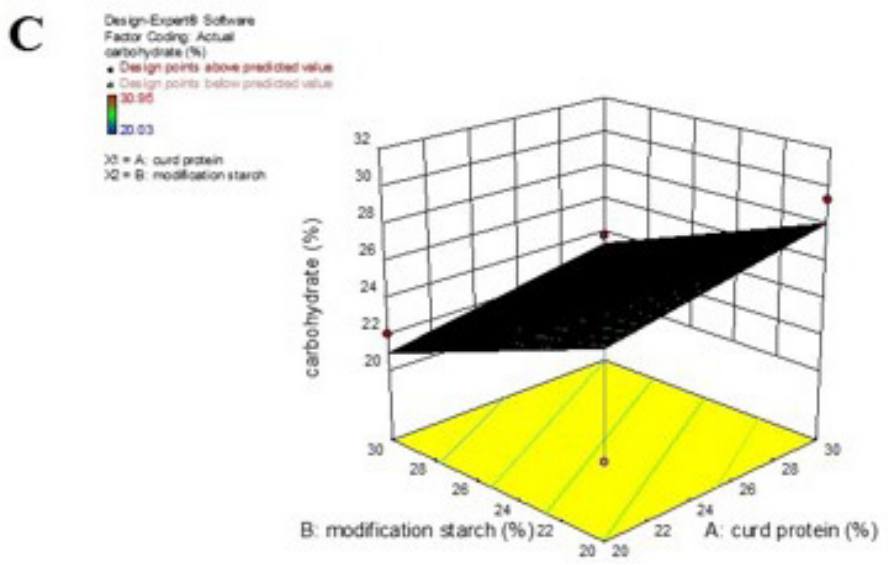

Figure 3. 3D Surface (A) ash content values (curd protein: modified starch) (B) value of fat content (curd protein: modified starch) (C) value of carbohydrate content (curd protein: modified starch).

(2009) state that the water content in the product decreases with increasing temperature, so that the higher the boiling temperature, the more water content is present in the product that evaporates. More and more additions of modified starch cocoyam water content in meat analog products are high because of the increased ability to bind water to modified starch due to the gelatinization process during heating. In accordance with the statement of Zaidul et al. (2007), gelatinization is a gel formation phenomenon that begins with the swelling of starch granules due to water absorption. The process of heating the dough will cause the granule to swell due to more water absorption. Furthermore, the development of starch granules is also caused by the entry of water into the granules and is trapped in the arrangement of the molecules making up starch.

\subsection{Protein content}

The linear model prediction was selected by the program to explain the relationship of curd concentration in cowpea protein and modified starch to the response of protein meat analog levels. The surface response to protein content can be seen in Figure 1B.

$\mathrm{Y}=18.26+0.62 \mathrm{X}_{1}+0.056 \mathrm{X}_{2}$ while $\mathrm{Y}=$ protein content response

$\mathrm{X}_{1}=$ curd protein

$\mathrm{a}=$ constant $(18.26)$

$\mathrm{X}_{2}=$ modified starch

Based on the Equation 5, it can be seen that curd protein has a coefficient of +0.62 , which indicates an increase in protein content in each addition of curd. Modified starch of cocoyam has a coefficient of +0.056 , which indicates an increase in protein content in each addition of modified starch.

Increased protein levels along with the addition of cowpea curd can be caused by the number of sources of protein added to the product, the more sources of protein added, and a higher amount of protein in the product. The protein content of cowpea curd protein is $12.14 \%$. There is a tendency that artificial meat protein levels are directly proportional to the higher concentration of isolates in meat analogs, or inversely proportional to the reduced concentration of flour added to make these artificial meat products (Taghdir et al., 2016). The fish meatball protein value with the addition of soybean protein isolates is higher than fish meatballs, which are not added with soy protein isolates in the processing. 


\subsection{Texture}

The prediction of the mean model was chosen by the program to explain the relationship of curd concentration of cowpea protein and modified cocoyam starch to the response of the texture of the meat analog. Surface response to texture can be seen in Figure 2A, which results in a Y value of 0.072 where $\mathrm{Y}=$ texture response.

Based on the equation above, it can be seen that the value of textures obtained from all formulations is average, and is equal to 0.072 . Both of the variable factors, namely cowpea protein curd and modified starch of cocoyam, do not affect increasing or decreasing the texture possessed by meat analog products so that the surface formed on 3D surfaces is flat at each level.

The texture of the meat analog is influenced by the ability to bind water and oil to the raw material, namely modified cocoyam starch. The cocoyam starch has undergone a physical modification, which causes a slight increase in WHC and OHC, but the effect is not significant on the texture of meat analog products.

The two independent factors used in meat analog do not affect texture. Singh et al. (2008) stated that chicken nuggets with the addition of $10 \%$ cowpea flour did not significantly influence the texture of the cooked nuggets. However, this is different from the statement of Naveena et al. (2006) that the increase in the texture of chicken nuggets and chicken patties after cooking is a result of the addition of cowpea and/or peanut flour and millet flour.

This texture of the meat analog is formed because of the interaction between the amino acids present in the protein and the hydrocolloid curd in the modified starch of the cocoyam. In accordance with Kweldam's (2011) statement, a fibrous texture can be obtained from mixing proteins with hydrocolloids that settle due to multivalent cation bonds. Supported by the statement of van der Goot et al. (2016) on most techniques, isolates of proteins and concentrates have the potential as raw materials with some addition of polysaccharides/hydrocolloids. Here the difference in texture can occur due to functional groups in proteins formed into spinning so that it can reduce cooking losses.

\subsection{Color (Lightness)}

The prediction of the mean model was chosen by the program to explain the relationship between the curd concentration of the cowpea protein and modified starch to the response of the color of the meat analog. The surface response to color (lightness) can be seen in Figure 2B.

$\mathrm{Y}=30.41$

where $\mathrm{Y}=$ texture response

$\mathrm{a}=$ constant $(30.41)$

Based on the Equation 6, it can be seen that the addition of curd of cowpea protein and modified starch of cocoyam did not affect meat analog products, with an average yield of +30.41 . This is because the raw materials used do not have identical colors. However, the colors in the modified starch are slightly darker, giving rise to a less attractive color of 30.93 in the $\mathrm{L}$ value and the meat analog values having a color of 30.41 in the $L$ value.

A decrease in lightness in the meat analog can be caused by a Maillard reaction that occurs between proteins and carbohydrates that are affected by the heating process. Kurnianingtyas et al. (2014) state that the higher the concentration of red bean flour, the darker the resulting color will be. Red bean flour contains proteins and carbohydrates, which are high enough that, when mixed with other ingredients, it will cause a Maillard reaction that produces dark colors that are increasing in processed products as the proportion of the ingredients used increases. Supported by Tamanna \& Mahmood statement (Tamanna \& Mahmood, 2015), the Maillard reaction is also called a non-enzymatic browning reaction. When food is processed or cooked at high temperatures, chemical reactions that occur between amino acids and reducing sugars produce different flavors and darker or browner colors so that they are commonly used in industries to give different tastes, colors, and aromas.

\subsection{Ash content}

The model that results from the processing of Design Expert is shown in Equation 7:

$Y=2.79-0.71 X_{1}+0.43 X_{2}-1.02 X_{1} X_{2}$

where $\mathrm{Y}=$ response ash content

$\mathrm{X}_{2}=$ modified starch

$\mathrm{a}=\mathrm{constant}$

$\mathrm{X}_{1} \mathrm{X}_{2}=$ curd protein ${ }^{\star}$ modified starch

$\mathrm{X}_{1}=$ curd protein

The modified tuber starch modification showed a different coefficient of +0.43 , which indicates that the higher ash content during the increase in the modified starch concentration was not significant because of $\mathrm{P}=0.2225$. The interaction between curd protein and modified starch has a coefficient of -1.02 , indicating a decrease in ash content during the interaction between the two ingredients because $\mathrm{P}=0.0560$.

The ash content of the meat analog is influenced by the mineral content contained therein; the higher the mineral content, the more the ash content in the product also increases. The difference in the ash content in the meat analog is due to differences in ash content in the curd protein that are equal to $0.17 \%$, and a modified tuber starch modification of $0.27 \%$ has no significant effect on the product because the number of minerals in both ingredients is equally low. However, the ash content in the modified tuber starch has a higher autoclaving-cooling method so that the higher the addition of modified tuber starch, the more the ash content of meat analog products will increase. Nurhartadi et al. (2014), using a protein source of red bean curd and winged bean flour fillers, states that the use of fillers shows that the ash content obtained has increased along with the addition of the wing bean flour filler ratio. This happens because the mineral content of the filling material, which is winged bean flour, is higher than that of the curd protein. The more filling material used in making the red bean meat analog, the higher the ash content of the meat 
analog produced. A contour image of ash content and 3D surface ash content values can be seen in Figure 3A.

Based on Figure 3A, it can be seen that there is no change in the addition of curd proteins at each concentration level. However, different starch modifications at low concentrations show a low surface, but along with increasing concentrations, the surface will be higher at the addition of $26.8 \mathrm{gr}$ of $4 \%$ ash content.

\subsection{Fat content}

The model resulting from the processing of Design Expert is shown in Equation 8:

$Y=2.59+0.11 X_{1}+1.26 X_{2}$

where $\mathrm{Y}=$ response fat content

$\mathrm{X}_{1}=$ curd protein

$\mathrm{a}=$ constant

$\mathrm{X}_{2}=$ modified starch

Ozturk et al. (2011) explain that the shortening of starch molecules caused by physical modifications of the branch chain indirectly increases the surface area so that the ability to interact with oil $(\mathrm{OHC})$ has increased. However, the increase is minimal because oil is hydrophobic. In this case, oil is thought to cover RS-3 only. The more fillers in a meat analog product, the more the fat content in the product will increase, as supported by Wu et al. (1997). The fat content of the red bean meat analog has increased along with the many additions of winged bean flour fillers. Winged bean flour contains starch, which can absorb water and oil. The contour and 3D surface of the meat analog fat content can be seen in Figure 3B.

Figure $3 \mathrm{~B}$ shows that there is no color change during the addition of curd protein. In contrast, the addition of modified starch shows a change in color from blue (20-21 gr) to green (25-28 gr) and finally reddish yellow (29-30 gr), which indicates that the concentration of starch is low and the fat content is low; conversely, the more the starch modification, the higher the increase in fat in meat analog products.

Figure $3 \mathrm{~B}$ shows that a fixed surface on the addition of curd proteins at each level of concentration is inversely proportional to the addition of the modified starch concentration, which changes at each level. The higher the modified starch concentration levels added, the higher the surface produced.

\subsection{Carbohydrate levels}

The model resulting from the processing of Design Expert is presented in Equation 9:

$Y=24.54+1.1 X_{1}-2.38 X_{2}$

where $\mathrm{Y}=$ response carbohydrate level

$\mathrm{X}_{1}=$ curd protein

$\mathrm{a}=$ constant

$\mathrm{X}_{2}=$ modified starch
Curd protein has a low starch content of $2.9 \%$, while the modified tuber root starch has a coefficient of -2.38 , which shows a significant decrease in carbohydrate content with a P-value of 0.0234 due to a long boiling process, which is 20 minutes. This can cause amylose out of starch granules, resulting in a significant decrease in carbohydrate levels. This can be caused by the amylose fraction of water-soluble starch that will come out of the starch granules during the boiling process of meat analog products. Following the statement of Nintami \& Rustanti (2012), the existence of cooking losses is caused by the boiling process, which will accelerate the gelatinization process, thus increasing the amount of dissolved starch. This will cause the structure of the starch gel, especially the amylose fraction, to be weakened because it is partially absorbed by water. A weak bond makes it easy for water to get into the granules so that amylose is dissolved in water. The more extended the cooking time, the more the starch granules are distended and cannot return to their original condition so that the number of starch granules will decrease.

Materials containing high amounts of amylose, if the boiled amylose is extracted by hot water, look white like milk. The starch is heated in excess water, so starch gelatinization will occur where the granules will be damaged and come out of the hydroxyl group of amylose and amylopectin bonds because of the crystalline structure changes. The release of amylose from the starch granules can also be called amylose leaching (Sagum \& Arcot, 2000). The contour and 3D surface meat analog carbohydrate levels can be seen in Figure 3C.

Based on Figure 3C, the addition of curd proteins shows a change in the surface, which becomes higher, while the surface decreases when the addition of modified starch is higher.

The response was optimized using the Design-Expert version 10 application. Optimization of the independent variable level (curd protein and modified starch) was obtained by optimizing the response (water content, ash, protein, fat, carbohydrate, texture, and color) based on the Indonesian national standard regarding the requirements for combination sausage meat and the results of Ratnawati et al. (2018) about analog sausages.

The optimal point on meat analog is as follows: protein curd $30 \%$, modified starch $30 \%$, response of water content $50.92 \%$, ash content $2.11 \%$, protein content $18.97 \%$, fat content $4.18 \%$, carbohydrate content $23.82 \%$, texture $0.075(\mathrm{~mm} / \mathrm{gr} / \mathrm{dtk})$, and color 22.44(L).

\section{Conclusions}

This study explains that the formulation of curd of cowpea protein and modified starch were suitable for meat analog. RSM succeeded in determining the optimum meat analog point, namely in the formulation of $30 \%$ curd protein and $30 \%$ modified starch, with moisture content, protein content, texture, and color that can produce products with good physical attributes and nutritional value that meet the requirements so that this product is ideal in replacing processed meat products. 


\section{References}

Abbasi, S., Mousavi, M., Mohabi, M., \& Kiani, S. (2009). Effect of time and temperature on moisture content, shrimkage, and rehydration of dried onion. Iranian Journal of Chemical Engineering, 6(3), 57-70.

Ahirwar, R., Jayathilakan, K., Reddy, K. J., Pandey, M. C., \& Batra, H. V. (2015). Development of mushroom and wheat gluten-based meat analog by using response surface methodology. International Journal of Advanced Research, 3, 923-930.

Antova, G. A., Stoilova, T. D., \& Ivanova, M. M. (2013). Proximate and lipid composition of cowpea (Vigna unguiculata L) cultivated in bulgaria. Journal of Food Composition and Analysis, 33(2), 146-152. http://dx.doi.org/10.1016/j.jfca.2013.12.005.

Apostolidis, C., \& McLeay, F. (2016). Should we stop meating like this? Reducing meat consumption through substitution. Food Policy, 2016(65), 74-89. http://dx.doi.org/10.1016/j.foodpol.2016.11.002.

Association of Official Analytical Chemists - AOAC. (1995). Official methods of analysis of the Association of Official Analytical Chemists. Washington: AOAC.

Boakye, A. A., Wireko-Manu, F. D., Oduro, I., Ellis, W. O., Gudjónsdóttir, M., \& Chronakis, I. S. (2018). Utilizing cocoyam (Xanthosoma sagittifolium) for food and nutrition security: a review. Food Science \& Nutrition, 6(4), 703-713. http://dx.doi.org/10.1002/ fsn3.602. PMid:29983932.

Dekkers, B. L., Boom, R. M., \& van der Goot, A. J. (2018). Structuring processes for meat analogs. Trends in Food Science \& Technology, 81, 25-36. http://dx.doi.org/10.1016/j.tifs.2018.08.011.

Jalarama, R. K., Pandey, M. C., Harilal, P. T., \& Radhakrishna, K. (2013). Optimization and quality evaluation of freeze-dried mutton Manchurian. International Food Research Journal, 20, 3101-3106.

Kurnianingtyas A., Ninna, R., and Andrei, R. (2014). Effect of red bean flour addition againts acceptability, protein levels, and fiber levels on banana hearts meatballs. E-Jornal of Health Library, 2(3), 485-491.

Kweldam, A. C. (2011). Patent No. WO 2003/061400 A1. Genebra: World Intellectual Property Organization.

Larrauri, J. A., Rupérez, P., Bravo, L., \& Saura-Calixto, F. (1996). High dietary fibre powders from orange and lime peels: associated polyphenols andantioxidant capacity. Food Research International, 29(8), 757-762. http://dx.doi.org/10.1016/S09639969(97)00003-3.

Li, M. A., Kornacki, J. L., Zhang, G., Lin, C.-M., \& Doyle, M. P. (2007). Development of thermal surrogate microorganisms in ground beef for in-plant critical control point validation studies. Journal of Food Protection, 70(4), 952-957. http://dx.doi.org/10.4315/0362028X-70.4.952. PMid:17477266.

Madamba, P. S. (2002). The response surface methodology: an application to optimize dehydration operations of selected agricultural crops. Food Science and Technology (Campinas), 35, 584-592.

Montgomery, D. C. (2008). Design and analysis of experiment. Arizona: John Wiley and Sons Inc.

Myers, R. H., Montgomery, D. C., Vining, G. G., Borror, C. M., \& Kowalski, S. M. (2004). Response surface methodology: a retrospective and literature survey. Journal of Quality Technology, 36(1), 53-77. http:// dx.doi.org/10.1080/00224065.2004.11980252.

Naveena, B. M., Muthukumar, M., Sen, A. R., Babji, Y., \& Murthy, T. R. K. (2006). Quality characteristics and storage stability of chicken patties formulated with finger millet flour (Eleusina coracana). Journal of Muscle Foods, 17(1), 92-104. http://dx.doi.org/10.1111/j.17454573.2006.00039.x.
Nintami, A. L., \& Rustanti, N. (2012). Fiber levels, antioxidant activity, amylose, and wet noodles preference test with purple sweet potato flour substitution (Ipomoea batatas var Ayamurasaki) for type 2 diabetes mellitus patients. Journal of Nutrition College, 382-387.

Nurhartadi, E., Choirul, A., Dwi, I., Nur, H. P., Rysda, A. L., \& Nor, S. (2014). Meat analog from kidney bean protein curd (Phaseolus vulgaris L) using winged bean flour (psophocarpus tetragonolobus) as filler: physicochemical characteristic. J Tek Hasil Pertanian, 3, 12-19.

Ozturk, S., Koksel, H., \& Ng, P. K. W. (2011). Production of resistant starch from acid-modified amylotype starches with enhanced functional properties. Journal of Food Engineering, 103(2), 156-164. http://dx.doi.org/10.1016/j.jfoodeng.2010.10.011.

Rahayu, W. P., \& Nurosiyah, S. (2012). Sensory evaluation. In: Sensory evaluation and its development (pp. 1-36). Jakarta: Open University.

Ratnawati, S. E., Ekantari, N., Pradipta, R. W., \& Pramita, B. L. (2018). Application of response surface metodology (RSM) in calcium optimization of catfish bones extraction. Jurnal Perikanan UGM, 20, 41-48.

Rekha, C. R., \& Vijayalakshmi, G. (2010). Influence of natural coagulants on isoflavones andantioxidant activity of tofu. Journal of Food Science and Technology, 47(4), 387-393. http://dx.doi.org/10.1007/s13197010-0064-7. PMid:23572658.

Sagum, R. S., \& Arcot, J. (2000). Effect of domestic processing methods on the starch, non-starch polysaccharides and in vitro starch and protein digestibility of three varieties of rice with varying levels of amylose. Food Chemistry, 70(1), 107-111. http://dx.doi.org/10.1016/ S0308-8146(00)00041-8.

Schoch, T. (1964). Swelling power and solubility of granular starches. Methods Carbo Chem, 4, 106-108.

Sin, H. N., Yusof, S., Sheikh Abdul Hamid, N., \& Rahman, R. A. (2006). Optimization of enzymatic clarification of sapodilla juice using response surface methodology. Journal of Food Engineering, 73(4), 313-319. http://dx.doi.org/10.1016/j.jfoodeng.2005.01.031.

Singh, O. P., Singh, J. N., Bharti, M. K., \& Kumari, S. (2008). Refrigerated storage stability of chicken nuggets containing pea flour. Journal of Food Science and Technology, 45, 460-462.

Sugiyono, Pratiwi, R., \& Faridah, D. N. (2009). Arrowroot (Marantha arundinacea) starch Modification through autoclaving cooling cycling treatment to produce resistant starch type III. Jurnal Teknologi Dan Industri Pangan, 20(1), 17-24.

Taghdir, M., Mazloomi, S. M., Honar, N., Sepandi, M., Ashourpour, M., \& Salehi, M. (2016). Effect of soy flour on nutritional, physicochemical, and sensory characteristics of gluten-free bread. Food Science \& Nutrition, 5(3), 439-445. PMid:28572928.

Tamanna, N., \& Mahmood, N. (2015). Food processing and maillard reaction product: effect on human health and nutrition. International Journal of Food Sciences, 2015, 1-6. http://dx.doi.org/10.1155/2015/526762.

van der Goot, A. J., Pelgrom, P. J. M., Berghout, J. A. M., Geerts, M. E. J., Jankowiak, L., Hardt, N., Keijer, J., Schutyser, M. A. I., Nikiforidis, C. V., \& Boom, R. M. (2016). Concepts for further sustainable production of foods. Journal of Food Engineering, 168, 42-51. http:// dx.doi.org/10.1016/j.jfoodeng.2015.07.010.

Wu, W.-H., Lu, J. Y., Jones, A. R., Mortley, D. G., Loretan, P. A., Bonsi, C. K., \& Hill, W. A. (1997). Proximate composition, amino acid profile, fatty acid composition, and mineral content of peanut seeds hydroponically grown at elevated $\mathrm{CO}_{2}$ levels. Journal of Agricultural and Food Chemistry, 45(10), 3863-3866. http://dx.doi.org/10.1021/jf970077f.

Zaidul, I. S. M., Yamauchi, H., Takigawa, S., Matsuura-Endo, C., Suzuki, T., \& Noda, T. (2007). Correlation between the compositional and pasting properties of various potato starches. Food Chemistry, 105(1), 164-172. http://dx.doi.org/10.1016/j.foodchem.2007.03.061. 